\title{
Preface
}

\section{Lucan Way}

Published online: 18 December 2015

(C) Springer Fachmedien Wiesbaden 2015

Since Steven Levitsky and I first wrote about hybrid regimes in the early 2000 s, the concept of competitive authoritarianism has resonated more than he and I could have hoped. In fact, the term is often used without citing us - a sure sign of success. This and other new work - exemplified by the essays in this special volume-have offered important insights into hybrid rule.

The concept of competitive authoritarianism originally emerged out of a comparison of corruption scandals in Peru and Ukraine in the early 2000s. We noticed that the two countries exhibited characteristics of a novel regime type. On the one hand, both regimes were highly authoritarian. Autocrats engaged in widespread harassment of opposition, attacks on media, and abuse of state resources. Yet both regimes were also highly competitive. Parliaments had real power, media was often critical of incumbents, and elections were hotly contested. Our initial inclination was to use existing terminology to describe this regime type. As Richard Snyder has argued, scholars should resist inventing new concepts when existing terms suffice. ${ }^{1}$ But we quickly realized that older terms did not adequately describe this new phenomenon. For example, "electoral authoritarianism," a term proposed at the time by Andreas Schedler, describes any regime that is both authoritarian and has multiparty elections. ${ }^{2}$ This concept encompasses many cases in which multiparty elections are merely a façade, as in Uzbekistan. In the cases we were trying to describe, by contrast, competition is in fact real but unfair. Similarly another term, Freedom House's "partially

\footnotetext{
${ }^{1}$ Richard Snyder. 2006. Beyond Electoral Authoritarianism: The Spectrum of Non-Democratic Regimes. In Electoral Authoritarianism: The Dynamics of Unfree Competition, ed. Andreas Schedler, 292-310. Boulder, CO: Lynne Rienner Publishers.

${ }^{2}$ Andreas Schedler, ed. 2006. Electoral Authoritarianism: The Dynamics of Unfree Competition. Boulder, CO: Lynne Rienner Publishers.
}

Assoc. Prof. L. Way ( $\bowtie)$

University of Toronto,

Toronto, Canada

E-Mail: lucan.way@utoronto.ca 
free," also included a much broader range of regime types than we were trying to conceptualize.

So against our better judgment we decided to invent a new term that captured a phenomenon left obscured by existing terminology. Yet measuring this regime type presented significant challenges. The easiest and by far most common approach would have been to use existing datasets and measures from Polity or Freedom House. But such an approach was highly problematic for two reasons. First, as mentioned above, Freedom House's "partially free" encompasses a diverse range of regimes not captured by our concept - including tutelary military regimes such as Honduras, democracies such as Estonia and Latvia that severely limit the voting rights of minorities, and "soft monarchies" such as Jordan in which the top executive is not elected. Second, and relatedly, these scores are highly opaque. It is not at all obvious what the differences between a "4" and a "5" are in Freedom House's 7 point scale. Given that these scores describe a wide range of regimes, it is literally impossible to disagree with a particular scoring. For example, how can I know whether Moldova in 1993 was a " 5 " when there is no definition of what a " 5 " is? We might assess the validity of these scores by comparing regimes with the same ranking. But in reality, Freedom House (as well as many other indices) utilize quite different standards to score cases in different regions of the world. In areas such as Africa and the former Soviet Union, many observers have less demanding standards for democracy than they do in Latin America. For example, in 1997, Brazil — which was widely considered a full democracy_received a worse Freedom House score than either Malawi (where there were frequent attacks on the opposition and media) or Russia (where the government had bombed parliament and elections had been marred by fraud and manipulation). Such diverse standards result in the fact that these indices are primarily coded by regional experts who have their own — and largely unknown — criteria for assessing the level of democracy.

Thus we realized that we needed to develop an approach that was transparent, falsifiable, and that could be applied to any national government in the world. The end result was a list of quite specific criteria for coding competitive authoritarian regimes in the appendix of our book. They are extensive, which is largely a function of the multidimensional and complex character of regimes. In addition to this list of criteria, we provide specific indicator-level data on why we scored each case as competitive authoritarian in the appendix. The case studies in the main text offer detailed descriptions of specifically how and why we coded each case. Finally, in the introduction, we discuss a number of borderline cases and why we excluded them from the analysis (although the authors in this volume are correct that we might have included a systematic assessment of a larger range of these cases).

We fully expected that country experts would disagree with some of our codings, and in fact, that was the point of providing extensive and very specific coding rules. Our criteria are transparent enough that in contrast to Freedom House and some other rankings it is possible to disagree with them. Thus, although we would disagree with Bardall, whose essay in this volume criticizes our coding of specific cases, the fact that she has been able to use our criteria to identify new cases of competitive authoritarianism speaks to the transparency of our coding rules. It goes without saying that much more effort is required to apply our criteria than some other available clas- 
sifications - such as "electoral authoritarianism"3 and NELDA ${ }^{4}$ - that code regimes as hybrid simply if they have multiparty elections. But the advantage of our criteria is that it captures actual regime dynamics described in our concept, including nonelectoral dimensions mostly ignored in other classifications. While easy replicability is important, it is also critical to get cases right.

Levitsky and I started this project with an analysis of Ukraine and Peru. Yet, it turned out that Africa was the region where competitive authoritarian regimes were most prevalent. Given the relative dearth of major oil producers or large and powerful states, countries in the region are mostly low leverage (as well as low linkage) and therefore subject to at most sporadic Western democratizing pressure. In addition, the region includes large numbers of weak states. Consequently, incumbents have had a relatively difficult time sidelining even weak opposition. At the same time, most African states lack the standard prerequisites-well developed economies, strong civil societies - for stable democracy. The result has been various forms of hybrid rule.

The large number of African competitive authoritarian regimes (and the fact that neither Levitsky nor I are experts on the region) make this special issue particularly worthwhile. First, Bardall and Helle offer some thought-provoking ideas about how to refine the operationalization of our concepts. This is especially worthwhile with regards to the concept of a level playing field, which is both relatively novel and presents particularly thorny issues of measurement. At the same time, as discussed above, the authors are incorrect in claiming that our framework is "impossible to falsify" or that we fail to provide indicator-level data.

Second, a number of authors in this issue apply our ideas to cases outside the scope of our original study. Hartmann and van Eerd examine the impact of linkage and leverage of regional actors within Africa not included in our book. In a similar vein, Southall contends that linkage and leverage may explain why South Africa democratized despite being dominated by a highly cohesive African National Congress. Focusing on Tanzania, Makulilo offers a valuable analysis of subnational governments that were not the object of our original study. Next, Cassani and Carbone explore the socio-economic consequences of competitive authoritarianism. They suggest, surprisingly, that such rule may lead to social improvements.

Finally, Hill and Kagoro respectively explore the origins and impact of coercive capacity in two regimes that emerged out of violent struggle: Algeria (a fully authoritarian regime) and Uganda (which only later became competitive authoritarian). It is particularly gratifying to see that our theory helps us to understand cases that were not originally part of our study. In fact, both of these cases are quite pertinent to our next book - The Durability of Revolutionary Regimes - that examines the impact of violent revolutionary struggle on authoritarian durability. We can only hope that this new book will generate the kind of fruitful discussion and critique found in this special issue.

\footnotetext{
${ }^{3}$ Andreas Schedler, ed. 2006. Electoral Authoritarianism: The Dynamics of Unfree Competition. Boulder, CO: Lynne Rienner Publishers.

${ }^{4}$ Susan D. Hyde and Nikolay Marinov. 2009. National Elections across Democracy and Autocracy: Putting the "Competitive" into Competitive Authoritarianism. Unpublished manuscript. New Haven, CT: Yale University.
} 